\title{
Experimental Comparison of Co-gasification Charateristic of Rice Husk Pellet and Rice Husk Mixtures:
}

\author{
Pyrolysis Zone Optimization
}

\author{
Apri Wiyono*, Ridwan A. M. Noor \\ Dept. of Automotive Engineering Education \\ Universitas Pendidikan Indonesia \\ Bandung, Indonesia \\ apri.wiyono@upi.edu,adam@upi.edu
}

\author{
Ega Taqwali Berman, Asep Setiadi Husen, Mutaufiq \\ Dept. of Mechanical Engineering Education \\ Universitas Pendidikan Indonesia \\ Bandung, Indonesia \\ egatb@upi.edu, asepsetiadihusen@upi.edu, \\ taufiq_top@upi.edu
}

\begin{abstract}
Raise of energy demand, in line with the rate of population growth is always followed by waste volume increasing. Where the largest percentage comes from organic waste, it is potentially utilized as raw material of biomass mixture for emission reduction efforts on fuel conversion from waste energy. The main objective of this paper is to study the characteristic of co-gasification, especially gasification temperature, lower heating value and gas emission, on the performance of the biomass gasification process in a downdraft fixed bed gasifier. In this study, organic waste used twigs of rice husks in the pelletization as raw materials on combustion technology Downdraft Gassifier. Methods were carried out by cogasification techniques between rice husk, mixture and RH (rice husk) pellet. Where syngas testing is done direct measurement on burner with TCD gas chromatography. The flaming pyrolisis temperature in the reactor is $700 \mathrm{C}-750^{\circ} \mathrm{C}$ and the temperature in the combustion zone is $900 \mathrm{C}-1100^{\circ} \mathrm{C}$. The result of the syntetic gas testing obtained the highest lower heating value in rice husk pellet $100 \%$ composition at $2.68 \mathrm{MJ} / \mathrm{Nm}^{3}$. The lower the calorific value of the raw material in the fuel composition, the smaller the LHV syngas output, where an increase in RH pellets will increase the LHV syngas value. This resulted in visually low tar content and low ash particles in all compositions of about $30 \%$ of the initial mass of each composition according to the experimental literature, with the lowest ash in the $100 \%$ rice husk pellet composition predicting yield.
\end{abstract}

Keywords-pelletization, co-gasification, downdraft gasifier, syntetic gas, biomass

\author{
Rany Anggrainy \\ Dept. of Mechanical Engineering \\ Universitas Krisnadwipayan \\ Jakarta, Indonesia \\ rani.anggrainy@gmail.com
}

\author{
Haikal \\ Dept. of Mechanical Engineering \\ Sekolah Tinggi Teknologi Warga Surakarta \\ Surakarta, Indonesia \\ basalamahhaikal3@gmail.com
}

\section{INTRODUCTION}

Waste in Indonesia is one of the biggest environmental problems because as the population increases, the correlation with the more waste generated. In 2015 Indonesia produces 175,000 tonnes of waste / day or 64 million tons / year equivalent [1]. Reserves of energy sources need to be taken several preventive measures so that these reserves can be used as wealth that can be enjoyed by future generations, instead of long-term energy supply considering various other aspects, such as environmental, economic, and social human aspects. The application of advanced technology requires education and sufficient information so that it can be accepted by people who have never interacted with various new technologies for EBT (New and Renewable Energy) and the impact of their utilization on social humanity [2-4].

Nearly $80 \%$ of world energy consumption comes from fossil fuels which disturb the environment and health due to increased emissions of $\mathrm{CO} 2, \mathrm{NOx}$ and $\mathrm{SO} 2$. Biomass is an applicative renewable energy source for clean energy production to zero greenhouse carbon $(\mathrm{CO} 2)$ emissions and relatively low levels of NOx [5]. After fossil fuels, biomass is the fourth largest energy source in the world. Biomass supplies approximately $11-12 \%$ of the world's primary energy consumption. In developing countries, biomass is the most important energy, accounting for approximately $38 \%$ of the total primary energy consumption and in rural areas approximately $90 \%$ of the total energy supply. Estimated $90 \%$ 
of the world's population in the developing region by 2050 , biomass energy will remain a source of substantial energy reserves [6-8].

The negative impact of large piles of waste can be reduced if it can be reused by processing the conversion of fuel from waste energy. Where the largest percentage of waste comes from organic waste components with an average percentage of $75 \%$ [9]. So far in 2015, the most researched case studies in the field of waste to energy are incineration while the smallest number of studies is pyrolysis / gasification and combustion technology in detail [9]. Therefore, it is necessary to conduct more intensive research to increase the contribution of waste processing into energy with gasification technology. Biomass gasification is a thermochemical process to convert biomass raw materials into gas fuel or chemical gas fuel (synthetic gas) with low environmental impact, resulting in the production of combustion gases (a mixture of $\mathrm{CO}, \mathrm{H} 2$ with a little added $\mathrm{CH} 4$ ), containing up to $80 \%$ of biomass energy and reduce global CO2 emissions [10].

The parameters for the shape, size and structure of the fuel in biomass gasification are not the same. Some of the most commonly used methods are fixed-bed biomass gasification, entrained flow bed, fluidized-bed gasifier, downdraft gasifier and updraft gasifier. The downdraft gasifier was chosen because it produces less synthetic gas with tar [11]. Biomass gasification in the downdraft gasifier reactor type has been implemented, one of which is in the ceramic industry using coconut shell, wood and rice husk as fuel with a variety of blending compositions. The experiment found that the pyrolysis zone temperature ranged from $103.97^{\circ} \mathrm{C}$ to $141.64^{\circ} \mathrm{C}$ [12]. However, in its application, the flame on the burner is less stable and the duration of the flame is shorter. Therefore, it is necessary to do densification / pelletization for the effectiveness of the combustion process such as consistency of quality, low water content, high energy content and homogeneity of the shape and size of biomass [13]. However, in the MSW co-gasification test, it was found that the size of the fuel was not uniform, which affected the lack of LHV syngas values produced [14]. In other research conducted using the co-pyrolysis method of sewage sludge and phytomass, there were advantages in terms of the quantity of bio-oil output but also difficulties in providing fuel to heat the reactor [15], in another case, co-gasification of refused derived fuel and biomass in a fluidized bed reactor obtained a reduction in tar output at the output of the gasification process but it has shortcomings for the choice and size of fuel that can be processed is very limited [16]. This illustrates that the biomass co-gasification method still has many shortcomings, both in terms of LHV syngas optimization and tar reduction. So, in this study a co-gasification study of pellet fuel or densification of organic waste was carried out on the aspect of temperature parameters in the pyrolysis zone of the draft fixed bed gasifier.

\section{MATERIALS AND METHODS}

\section{A. Biomass Material}

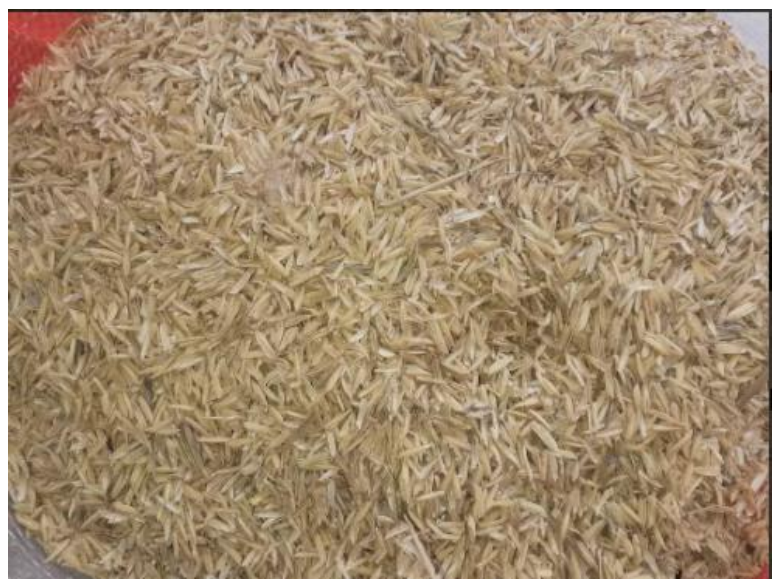

Fig. 1. Rice husk feedstocks.

Biomass used in this study is rice husk (figure 1), rice husk mixture and rice husk pellets. Before entering the pellet product manufacturing stage, it is necessary to carry out an analysis regarding the characteristics of the pellet-forming raw material itself. The aim is to obtain a suitable material mixture to obtain pellet products with high heating value and low emissions. In this case, proximate and ultimate analyzes have been carried out of the three type of biomass variation. However, there needs to be a mixture of rice husk and pellet form to increase the calorific value in the gasification process. In this experiment used mix method and densified fuels of rice husk which aims to determine the optimum composition in generating energy burning tar best with the lowest. Before the test, three samples dried in an oven (Memmert UL 30) at a temperature of $70 \mathrm{C}$. Fuels Characteristic testing by the proximate analysis of ASTM method D5142 and ASTM method D5373 for ultimate analysis. Properties of biomass sample can be seen in table 1 .

TABLE I. PROPERTIES OF BIOMASS SAMPLE

\begin{tabular}{|l|l|l|l|}
\hline & Rice husk Pellet & Rice husk & Blending 50:50 \\
\hline \multicolumn{3}{|c|}{ Bomb Calorimeter } \\
\hline $\begin{array}{l}\text { Caloric value } \\
\text { (cal/g) }\end{array}$ & 3986 & 3300 & 3500 \\
\hline \multicolumn{4}{|c|}{ Proximate Analysis } \\
\hline Moisture & 11.57 & 9.82 & 12.46 \\
\hline Volatile & 65.28 & 65.55 & 66.15 \\
\hline Fixed Carbon & 14.55 & 13.52 & 13.91 \\
\hline Ash & 8.61 & 10.61 & 9.58 \\
\hline Volatile Dry & 77.56 & 76.84 & 77.79 \\
\hline Ash Dry & 9.86 & 27.63 & 9.79 \\
\hline
\end{tabular}

\section{B. Methods}

In processing the biomass contained in various ways such as by carbonization, bio-oil, bio-drying and gasification. The technique chosen is the co-gasification technology, with the reasons for combining the fuel to obtain syngas heating value 
that is greater than the calorific value of each raw material. Cogasification technology is gasification joint between the two types of fuel, in this case the main fuel in the form of pellets (wood and coconut fiber) and rice husk. In type downdraft biomass gasification, gasification reactor is divided into 4 zones, including Drying, pyrolysis, Oxidation (combustion) and Reduction.

1) Pyrolysis [17]: The raw material is exposed to heat and will break down into lighter compounds at temperatures from 300 to $700^{\circ} \mathrm{C}$. If the parameters of operation are appropriate, flaming pyrolysis may occur, that is, pyrolysis products will get little air supply from the oxidation zone, causing fuel rich flame. In flaming pyrolysis, tar breaking or tar cracking occurs [18].

2) Oxidation [19]: Some pyrolysis and carbon products will react exothermally with oxygen, generating heat energy.

Pelletization was performed with a pellet press and durability test conducted on the product pellets produced from the molding tool to determine the strength and toughness of the characteristics of the pellets. From the pellets produced, tests are carried out to determine the durability of the products formed by the durability test. The durability test results are obtained by subtracting the final mass (after sieving) the initial mass. The PDI (Pellet Durability Index) value of rice husks was $81.42 \%$ and rice husk pellets were $90.35 \%$. Then, the PDI (Pellet Durability Index) value of a mixture of rice husks - rice husk pellets were also obtained, namely $86.87 \%$. Durability tester can be seen in figure 2 .

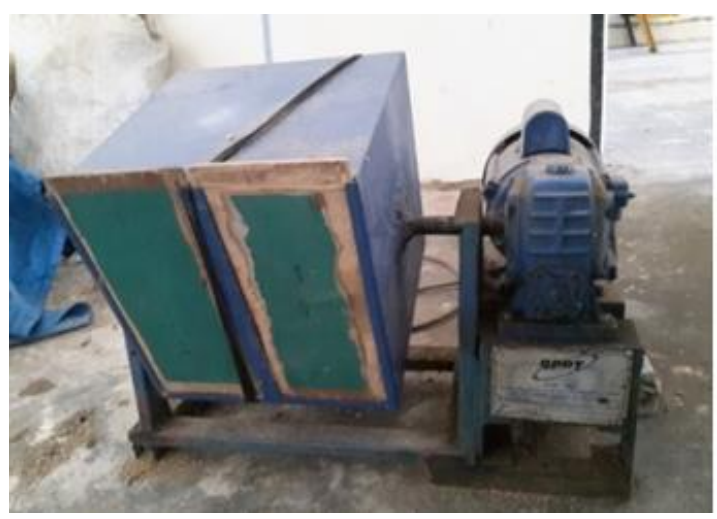

Fig. 2. Durability tester.

In this test set some conditions to facilitate the data collection and testing. The samples used are rice husk and rice husk pellet. Fuel is inserted into the reactor is $4 \mathrm{~kg}$ in one running. The density of the air $1.2 \mathrm{~kg} / \mathrm{m} 3$. The selection of the ER value (air supply) must match the needs. Thus, ER variation used in this study was 0:25. Fuel flowrate adjusted to the volume of the gasifier with a height of $18 \mathrm{~cm}$ from the grate. Which were obtained by the pellet mass of $4 \mathrm{~kg}$ and 0.8 $\mathrm{kg}$ of rice husk transform and reaches a height of the volume. Based downdraft gasification capacity of the medium $( \pm 1$ meter altitude reactor) and the type of fuel used [20]. The process used is the technique of co-gasification. Cogasification technique chosen because it can increase the calorific value of the gas producer and lower levels of $\mathrm{CO} 2$ and tar by combining two materials calorific value or more. This study used a different composition to obtain the best composition.

\section{RESULTS AND DISCUSSION}

A. Distribution temperature of Drying and Pyrolisis Zone

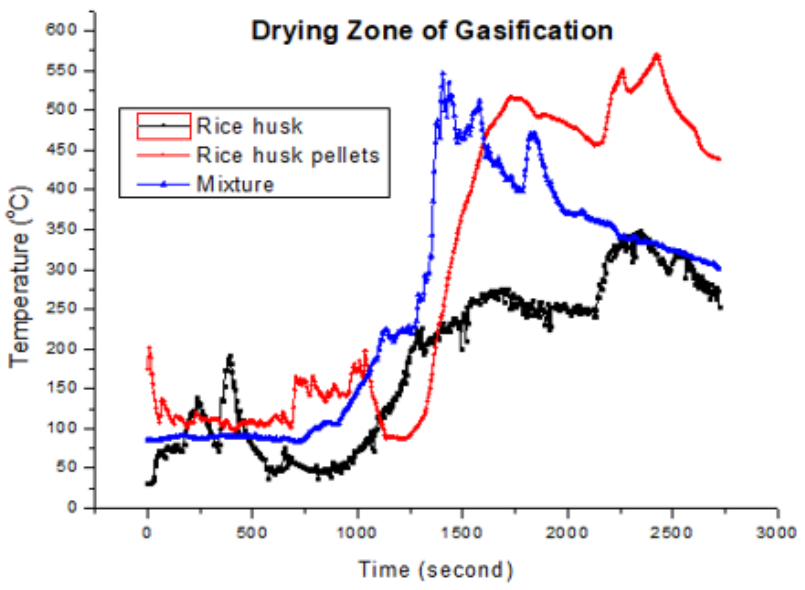

(a)

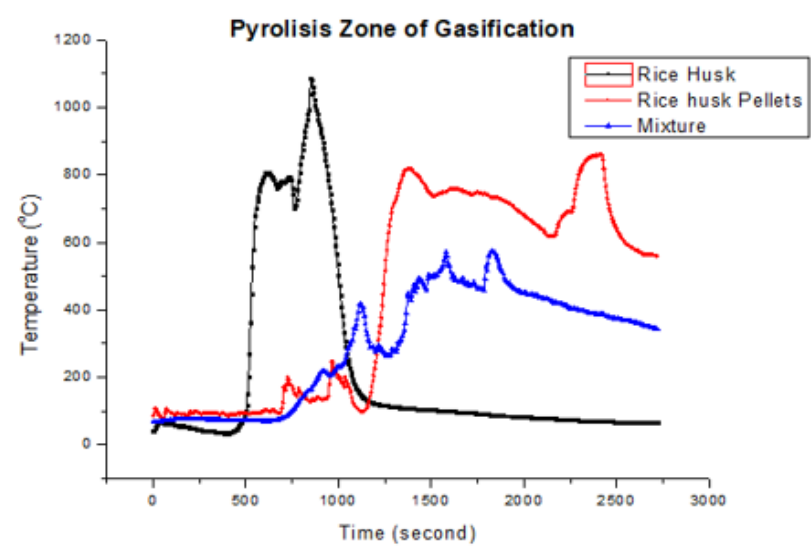

(b)

Fig. 3. Temperature distribution (a) Drying zone (b) Pyrolisis zone.

Changing the contents and types of coal and/or biomass in co-gasification has a significant effect on different output parameters such as gas production, carbon conversion, gas yield, cold gas efficiency, tar yield, caloric value and release of $\mathrm{H} 2 \mathrm{~S}$ and NH3 [21-23]. So, the raw material from the fuel and the blending process has a big influence in producing good combustion efficiency. This will also be an important factor in determining the quantity and quality of producer gas produced in the gasification process.

Figure 3 (a) shows the temperature distribution of the drying zone against time with variations in the rice husk fuel, 
husk mixture and pellets with the same feeding rate. In the picture, it can be seen that the drying temperature of the three variations of the fuel is quite high, up to $600 \mathrm{oC}$. Rice husks have a higher flash point because they are more flammable than others. Figure 3 (b) shows the temperature distribution of the pyrolysis zone against time with 3 variations of rice husk fuel, husk mixture and pellets with the same feeding rate and tool setting. The graph shows that the pyrolysis temperature of all variations has a pickup temperature from $550-800^{\circ} \mathrm{C}$. However, temperature stability is obtained at $100 \%$ variation of the fuel for rice husk pellets. This indicates that the production of $\mathrm{CO}$ and $\mathrm{H} 2$ is also quite high. Where is also directly proportional to the value of the LHV calculation [23]. Besides that, another factor that also affects producer gas output is tar content. This can be seen from the pyrolysis temperature of $100 \%$ rice husk pellet composition (red color), it can be seen that the pyrolysis zone temperature graph in this variation reaches a range of $800^{\circ} \mathrm{C}$ and stable at temperature $700^{\circ} \mathrm{C}$.

\section{B. Distribution Temperature of Combustion and Reduction Zone}

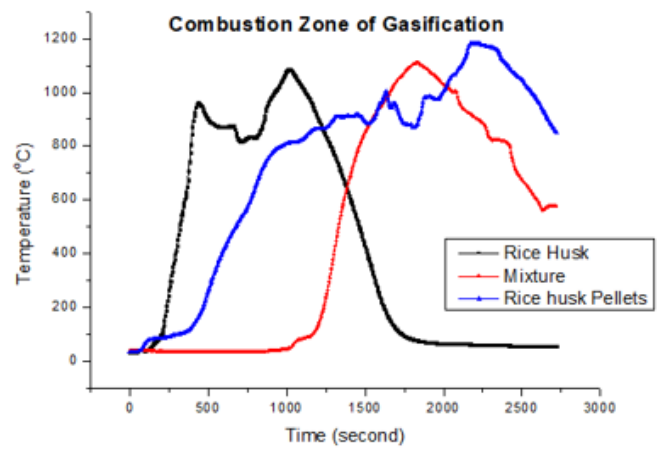

(a)

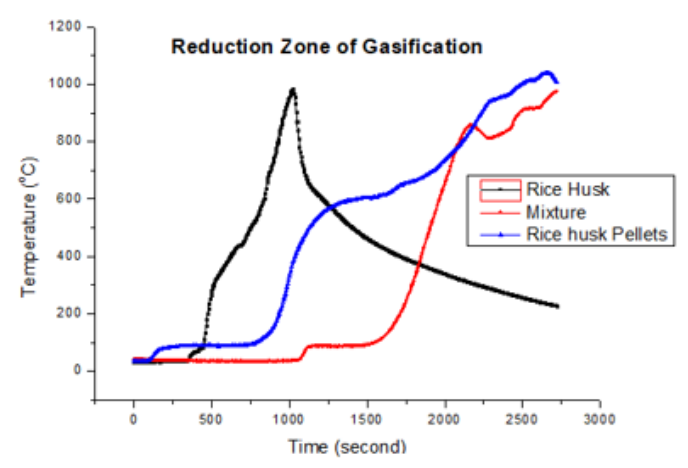

(b)

Fig. 4. Temperature distribution (a) Combustion zone (b) Reduction zone.

Figure 4 (a) shows the temperature distribution of the combustion zone against time with variations in the rice husk fuel, husk mixture and pellets with the same feeding rate. In the figure, it can be seen that the combustion temperature of the three fuel variations has a maximum temperature of up to $1100^{\circ} \mathrm{C}$. In the variation of the mixture and rice husk pellets, there was an increase and more temperature stability than rice husk. However, the variety of rice husk pellets has the most stable temperature among other variations. Figure 3 (b) shows the temperature distribution of the reduction zone in 3 variations of rice husk fuel, husk mixture and pellets. The graph shows that the reduction temperatures of all variations have a pick up temperature of up to $1000^{\circ} \mathrm{C}$. However, temperature stability is obtained at $100 \%$ variation of the fuel for rice husk pellets. This indicates that the production of combustible gas is high because the high temperature is able to degrade solid fuel into gas with high efficiency as well [24]. This can be seen from the pyrolysis temperature of the $100 \%$ rice husk pellet composition (red), it can be seen that the temperature graph of the reduction and combustion zones in this variation reaches a range of $1000^{\circ} \mathrm{C}$ to $1200^{\circ} \mathrm{C}$

\section{Tar Content}

On the graph it can be seen that the resulting pyrolysis temperature is in the range of $700-750^{\circ} \mathrm{C}$ in quite a long time and stable in the composition spaling rice husk pellet $100 \%$ This indicates that the temperature pyrolysis zone is quite stable at that value. By Suzdalenko et al., at a temperature of $500-800^{\circ} \mathrm{C}$ the pyrolysis area will produce the phenomenon of flaming pyrolysis [25]. Flaming pyrolysis is an event where most of the products of pyrolysis got a little supply of oxygen from the oxidation zone to produce a flame burning fuel-rich [26].

The higher the feeding rate, the tar production is increasing while the gas LHV decreases [27]. This can be proved by testing gas composition where in the increasing feeding rate, the gas composition of $\mathrm{CO}$ and $\mathrm{H} 2$ decreased cause LHV go down. In this study, gasification process gasification process. This resulted in visually low tar content and low ash particles in all compositions of about $30 \%$ of the initial mass of each composition according to the experimental literature, with the lowest ash in the $100 \%$ rice husk pellet composition predicting yield.

\section{Flame Burner}

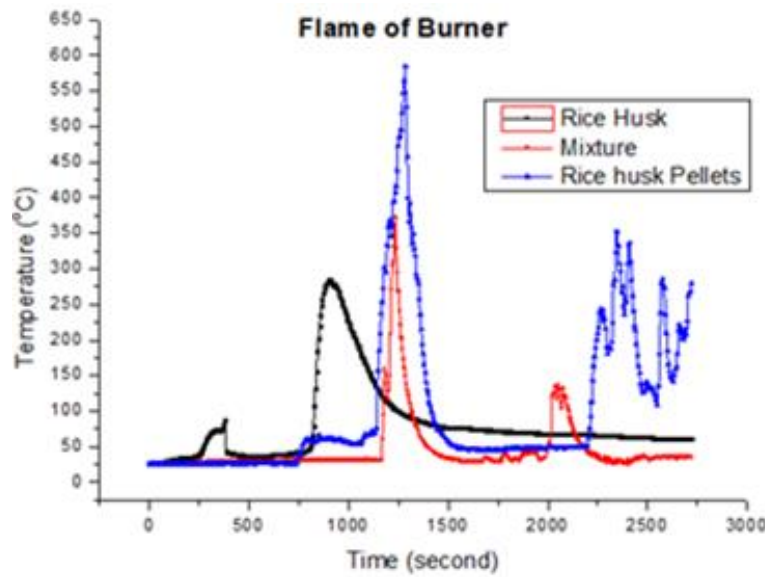

Fig. 5. Flame of burner. 
Figure 5 shows the duration of flame ignition during the gasification process of each of the test variations. The low tar content of the producer gas makes the syngas burning in the burner better. This can be seen from the burner temperature curve for each of the above compositions (colored blue) which has a high and stable temperature compared to the variety of husks and the mixture. In other words, the longer the temperature lasts (its stability) over the range, the more tar will be cracked.

\section{E. Energy Activation}

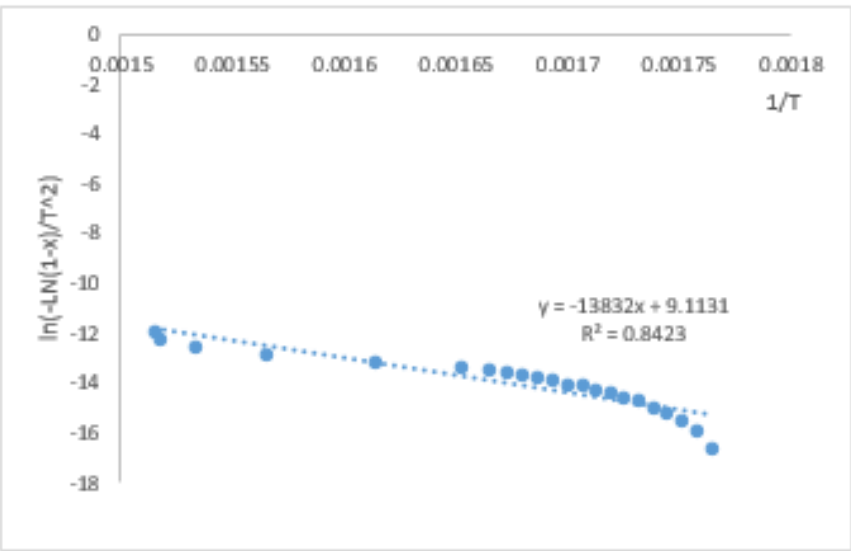

Fig. 6. Determination energy activation devolatilization of rice husk pellet.

Below is the calculation of activation energy of devolatilization by using thermogravimetry method. Where the value $\mathrm{R}=8,314 \mathrm{~J} / \mathrm{mol} . \mathrm{K}$. From the figure 6 , it can be seen that the activation energy $(\mathrm{Ea})$ using the thermogravimetric method for rice husk pellets is 196,446 kJ / mol. From the calculation of the smallest activation energy obtained from the variety of rice husk pellets, where the smaller the $\mathrm{Ea}$, the faster the reaction rate.

\section{CONCLUSION}

The highest flaming pyrolisis was in the composition of $100 \%$ rice husk pellets, as where high percentage of CO and $\mathrm{H} 2$ gas on the $\mathrm{RH}$ pellet composition on $700-750^{\circ} \mathrm{C}$. The lowest ash content approximately $30 \%$ occurred in the composition of rice husk pellet than blending mixture and $\mathrm{RH}$ pellets. This shows that the better combustion process, can produce the less ash content. Comparison of the advantages of husk and husk pellets are RH pellets (density, fuel homogenity, gas composition, LHV fuel, LHV syngas, burning time, pyrolysis \& oxidation temperature); rice husk (low ash content, faster startup time, simple processing).

\section{ACKNOWLEDGMENTS}

The authors would like to gratefully acknowledge LPPM UPI, Universitas Pendidikan Indonesia [Number 1079/UN40/PM/2020] for providing financial support. Thanks to Automotive Laboratory and Refrigeration \& Air Conditioning Laboratory, Faculty of Technology and
Vocational Education, Universitas Pendidikan Indonesia for technical support in this work.

\section{DISCLOSURE STATEMENT}

No potential conflict of interest was reported by the authors.

\section{REFERENCES}

[1] Kementerian Lingkungan Hidup dan Kehutanan Republik Indonesia "Plastic Waste Handling Dialogue," 2015. [Online]. Retrieved from: http://www.menlhk.go.id/rangkaian-hlh-2015-dialog-penanganansampah-plastik/

[2] Agenda Riset Nasional (2010-2014), Lampiran II Keputusan Menteri Riset dan Teknologi Nomor: 193/M/Kp/IV/2010. Tanggal : 30 April 2010

[3] Kebijakan Energi Nasional (Perpres No.5/2006)

[4] Undang-undang UU 30/2007 Tentang Energi dan PP 70/2009 Tentang Konservasi Energi.

[5] Y. Li and H. Liu, "High-pressure densification of wood residues to form an upgraded fuel," Biomass and Bioenergy, vol. 19, no. 3, pp. 177-186, 2000 .

[6] R. Sims, "Climate change solutions from biomass, bioenergy and biomaterials," 2003.

[7] A. Wiyono, I.M. Gandidi, E.T. Berman, and N.A. Pambudi, "Design, development and testing of integrated downdraft gasifier and multi IGCS system of MSW for remote areas," Case Stud. Therm. Eng., p. $100612,2020$.

[8] J. Zheng, X. Zhu, Q. Guo, and Q. Zhu, "Thermal conversion of rice husks and sawdust to liquid fuel," Waste Manag., vol. 26, no. 12, pp. $1430-1435,2006$

[9] B.S. Pathak, "Biomass to power rural development," Proc. of Nationa Seminar on Biomass Based Decentralized Power Generation, vol. 3, no. 1, pp. 3-6, 2005

[10] B. Jenkins and P. Mullinger, Industrial and process furnaces: principles, design and operation. Elsevier, 2011.

[11] J. Werther, "Gaseous emissions from waste combustion," J. Hazard Mater., vol. 144, no. 3, pp. 604-613, 2007.

[12] A. Bach-Oller, K. Kirtania, E. Furusjö, and K. Umeki, "Co-gasification of black liquor and pyrolysis oil at high temperature: Part 1. Fate of alkali elements," Fuel, vol. 202, pp. 46-55, 2017.

[13] L. Ding, "Development of an ultra-small biomass gasification and powe generation system: Part 2. Gasification characteristics of carbonized pellets/briquettes in a pilot-scale updraft fixed bed gasifier," Fuel, vol. 220, pp. 210-219, 2018

[14] C.S. Lewin, A.R.F. de Aguiar Martins, and F. Pradelle, "Modelling, simulation and optimization of a solid residues downdraft gasifier: Application to the co-gasification of municipal solid waste and sugarcane bagasse," Energy, vol. 210, p. 118498, 2020.

[15] B. Urych and A. Smoliński, "Sewage sludge and phytomass co-pyrolysis and the gasification of its chars: A kinetics and reaction mechanism study," Fuel, vol. 285, p. 119186.

[16] D.T. Pio, L.A.C. Tarelho, A.M.A. Tavares, M.A.A. Matos, and V. Silva "Co-gasification of refused derived fuel and biomass in a pilot-scale bubbling fluidized bed reactor,” Energy Convers. Manag., vol. 206, p. 112476, 2020

[17] H. Shi, N. Mahinpey, A. Aqsha, and R. Silbermann, "Characterization, thermochemical conversion studies, and heating value modeling of municipal solid waste," Waste Manag., vol. 48, pp. 34-47, 2016.

[18] V.C.J. Singh and S.J. Sekhar, "Performance studies on a downdraft biomass gasifier with blends of coconut shell and rubber seed shell as feedstock," Applied thermal engineering, vol. 97, pp. 22-27, 2016. 
[19] T.K. Patra and P.N. Sheth, "Biomass gasification models for downdraft gasifier: A state-of-the-art review," Renew. Sustain. Energy Rev., vol. 50, pp. 583-593, 2015.

[20] A. Wiyono, N.A. Pambudi, M. Hijriawan, I.M. Gandidi, E.T. Berman, and M. Mutaufiq, "Dataset on the integrated downdraft gasifier and multi integrated gas cleaner system (IGCS) for municipal solid waste (MSW)," Data Br., p. 105521, 2020.

[21] G.C. Young, Municipal solid waste to energy conversion processes: economic, technical, and renewable comparisons. New York: John Wiley \& Sons, 2010.

[22] A.K. Sharma, "Experimental study on $75 \mathrm{kWth}$ downdraft (biomass) gasifier system," Renew. Energy, vol. 34, no. 7, pp. 1726-1733, 2009.

[23] C. Erlich and T.H. Fransson, "Downdraft gasification of pellets made of wood, palm-oil residues respective bagasse: experimental study," Appl. Energy, vol. 88, no. 3, pp. 899-908, 2011.
[24] B. Kjellström, A. Arvidson, H. Forslund, and I. Martinac, "Renewable Energy Technologies for Decentralised Rural Electricity Services," in Report from an international workshop held in Studsvik, Sweden, 2004, pp. 10-12.

[25] V. Suzdalenko, I. Barmina, A. Lickrastina, and M. Zake, "The effect of co-gasification of the biomass pellets with gas on the thermal degradation of biomass," fuel, vol. 5, no. 1, pp. 2-3, 2011.

[26] F. Guo, Y. Dong, L. Dong, and C. Guo, "Effect of design and operating parameters on the gasification process of biomass in a downdraft fixed bed: An experimental study," Int. J. Hydrogen Energy, vol. 39, no. 11, pp. 5625-5633, 2014.

[27] M. Balat, "Mechanisms of thermochemical biomass conversion processes. Part 2: reactions of gasification," Energy Sources, Part A, vol. 30, no. 7, pp. 636-648, 2008. 